\title{
IMPLEMENTATION OF CONSUMER PROTECTION ON EXECUTION OF UNREGISTERED FIDUCIARY WARRANTYAT PT.FEDERAL INTERNATIONAL FINANCE (FIF) OF BENGKULU BRANCH
}

By :

\section{Septeddy Endra Wijaya, Slamet Muljono, Herawan. Sauni}

\begin{abstract}
The execution of collateral in the financing institution as contained in the UUJF is clearly made by the creditor against the debtor whose is breach of contract, in which the execution of the creditor has a permanent legal forceand legitimate. However, for unregistered warranty in accordance with $U U J F$ would cause conflict. One of the conflicts that arises is the unprotected consumer rights. The purpose of this research is to understand and analyze the implementation of consumer protection on execution of fiduciary Warranty which is not registered at PT.Federal International Finance (FIF) of Bengkulu Branch. The method used was empirical juridical approach, by using qualitative analysis. Result of the research mentioned that implementation of consumer protection at execution of unregistered fiduciary Warranty at PT. Federal International Finance (FIF) of Bengkulu Branch was not in accordance with the provisions of applicable legislation where the execution of PT. Federal International Finance (FIF) of Bengkulu Branch was not accompanied by a fiduciary certificate and was not through previous mediation efforts so that the execution of nonregistered fiduciary warrantyviolated the rights of the debtor as a consumer.
\end{abstract}

Keywords: Consumer Protection, Execution, Fiduciary Warranty 


\section{A. INTRODUCTION}

\section{Background}

\section{Electronic fiduciary} registration is a new system in which electronic fiduciary registration is filed within the time limit specified in Article 4 of Government Regulation Number 21 of 2015 Regarding the Procedures for Fiduciary Warranty Registration and Fiduciary Security Fee Making Cost as follows:

"Application for registration of Fiduciary Warranty as referred to in Article 3 shall be filed within 30 (thirty) days from the date of the issuance of deed of Fiduciary Guaranty."

The fiduciary registration period provides an obligation to the creditor to register the Warranty object so that if there is a breach of the pledge then the creditor can directly execute the fiduciary warranty. Article 16 verse (1) letter $b$ of Government Regulation Number 21 of 2015 Regarding the Procedures for Registration of Fiduciary Warranty and Fiduciary
Warranty Fee Making Cost stipulated that one of the reasons for the removal of fiduciary is the release of the right to fiduciary Warranty by fiduciary recipients. The disposal of this right is also accompanied by an execution by the finance party.

Execution performed by the financing party in case of fiduciary registered security object can be done by mechanism and provision as regulated by Article 29 verse (1) ofUUJF which mentioned as follows:

(1) If the debtor or fiduciary is breach of contract, the execution of the object subject to fiduciary security may be made by:

a. Implementation of the executorial title as referred to in Article 15 verse (2) by fiduciary recipients;

b. Sale of objects that become the object of fiduciary Warranty on the fiduciary receiver through a public tender and to take out its receivables from the proceeds of sale;

c. Under-hand sale is made under the agreement of the fiduciary giver and 
receiver if in such a manner the highest price can be obtained which benefits the parties.

The execution of collateral in the financing institution as contained in the $U U J F$ is clearly made by the creditor against the debtor whose is breach of pledge, in which the execution of the creditor has a permanent legal forceand legitimate. However, for non-registeredwarranty in accordance with $U U J F$ will cause conflict. One example is the case of Etik Sri Sulanjari with PT.SinarmasMultifinance in District Court of Surakarta Number

\section{5/Pdt.G/BPSK/2012/PN.SK}

A. In that case, EtikSri Sulanjari made a loan of Rp.5.000.000, - to PT SinarmasMultifinance with fiduciary Warranty in the form of Suzuki motorbike and by PT SinarmasMultifinance the loan was approved amounting to Rp.4.500.000, - along with agreed interest for 24 months. In the course of this, Etikcould not pay installments on the 10th and 11th month, so Sinarmas party executedforcedly and unilateral and was not in accordance with the rules of law, where the Warranty is not registered as fiduciary Warranty based on the case Etik'ssister filed a lawsuit to the District Court of Surakarta. ${ }^{1}$ The case is one of the most frequent cases in the execution of Warranty goods in the nonbank financing institution agreement, where the execution is an execution of unregistered items in accordance with the provisions contained in UUJF.

$$
\text { Based on the }
$$
background above ultimately the author is interested to conduct further research on execution conducted by PT.Federal International Finance (FIF) of Bengkulu Branch and find out the protection of consumers. This research would further be compiled in a journal entitled:

"Implementation of

Consumer Protection on Execution of Unregistered

${ }^{1}$ putusan.mahkamahagung.go.id/putusan/d ownloadpdf/.../pdf, accessed on 14 ${ }^{\text {th }}$ of April 2017. 
Fiduciary Warranty at PT. Federal International

Finance (FIF) of Bengkulu Branch."

\section{Problem Identification}

1. The formulation of the issues raised in this journal was: How is the implementation of consumer protection on execution of unregistered fiduciary warrantyat PT.Federal International Finance (FIF) of Bengkulu Branch?

\section{B. RESEARCH METHODOLOGY}

The method used in this study by its nature is qualitative research with empirical law approach. Qualitative research is research using holistic approach, that is approach which require various information to be analyzed, so that can be understood certain aspect of human attitude. ${ }^{2}$ Type of research in this study is juridical empiricalresearch. Empirical legal research as a result of interaction between law sciences with other

${ }^{2}$ Sirman Dahwal, Pelaksanaan Perkawinan Beda Agama (Studi Berbagai Kasus Di Indonesia Priode Tahun 1986-2010), Jurnal Ilmu Hukum Bengkoelen Justice,Program Pasca Sarjana Ilmu Hukum vol.2.No.2.2012,pg.464-465. disciplines. $^{3} \quad$ According to

Abdulkadir Muhamad, empirical legal research is a legal research whose object of study includes the provisions and on the enactment or implementation of normative legal provisions (codification, law or contract) in action / in abstracto in every legal event taking place in the society (in concerto). ${ }^{4}$ The research location at Bengkulu City with the data collection was done by documentation study and interview to answer the issues raised, and compiled into scientific paper in the form of journal.

\section{RESULTS AND DISCUSSION}

The Implementation of Customer Protection on Execution of Unregistered Fiduciary Warranty at PT.Federal International Finance (FIF) Branch of Bengkulu

The financing institution is a business entity undertaken by financing activities in the form of funds provision or capital by not attracting funds directly from the

\footnotetext{
${ }^{3}$ Bahder Johan Nasution, MetodePenelitianIlmuHukum, MandarMaju, Bandung, 2008.,pg.123.

${ }^{4}$ Abdulkadir Muhamad, 2004, HukumdanPenelitianHukum, Citra Aditya Bakti, Bandung, pg. 134
} 
community. ${ }^{5}$ The financing is divided into two: the productive financing and customer financing. According to the Presidential Regulation No. 9 of 2009, the customer finance is a financing activity for the procurement of goods based on Customer needs with installment payments. Moreover the other definition, the customer finance is a loan or credit granted by a company to the debtor for the goods purchase and services to be directly consumed by Customers, and it is not for the purpose production or distribution. The companies that provide financing on top, called a customer finance company. ${ }^{6}$

The customer financing agreement involving three parties namely were the customer financing institutions (financing lenders or lender), the customers part (financing recipients or debtor), and the supplier (seller or supplier). In this customer financing system, the customer financing institutions to provide

${ }^{5}$ DahlanSiamat. The Financial Institutions Management, Second Edition, Faculty of Economics, University of Indonesia, Jakarta, 2001, p. 281.

${ }^{6}$ Kasmir. Banks and Other Financial Institutions. Jakarta: Rajawali Pers. 2008. p.23 financing in the form of loan for an item purchase. The customer will subsequently receive funding facility for the purchase of certain goods and repay its debt or installments at regular intervals to the customer finance institutions. The seller or supplier provides the goods that are paid by the customer finance agency, in the customer financing Warranty is required either movable or immovable objects.

The term of warranty is translation of the Dutch language, namely zekerheid or cautie; generally include ways to ensure compliance with the creditors' bill, in addition to the general debtor's liability to his goods. $^{7}$ The warranty in the form of objects that can be guaranteed to banks and non-bank financial institutions, must meet the requirements of good collateral such as: ${ }^{8}$

1. Can easily assist the acquisition of credit by the party in need;

2. Not weaken the potential (power) of the credit seeker

\footnotetext{
${ }^{7}$ Salim HS. The Development of Guarantees Law In Indonesia, PT. Raja GrafindoPersada, Jakarta, 2014, pp.21

${ }^{8}$ Ibid, pp 27-28.
} 
to undertake or continue his business;

3. Provide certainty to the lender.

The warranty objects on leasing must be registered with the Fiduciary Warranty registration. The warranty that in the form of objects in practice often lead to conflicts where when one party in this case the customer does not keep the promise of the Warranty in execution. The executions carried out must be in accordance with the provisions of the legislation so that the rights of customers remain protected.According to the Prana as legal staff of PT.Federal International Finance (FIF) Branch of Bengkulu, stated that the FIF always protect the rights of Customers and prior to the withdrawal or the execution, the legal parties of PT.Federal International Finance (FIF) Branch of Bengkulu "Always do some mechanism approach and coaching first, one of them is Process Desk Call or calling customer to inform about the timing of installment payment which have matured, visit the customer to remind (for who do not have telephone), do billing, send warning letter 1 ( one) and 2 (two) with the following conditions:

a. Given the timing of installment payment that was due to call or Sending Message Service (SMS), made to recipients who enter their phone number in the application of credit, delayed payment of 1 (one) to 2 (two) days, for those who do not have a telephone by visiting to remind.

b. If there is no response from the recipients in the first and second days, in the 3rd day of her Dept Account Revieble (AR) commissioned Collector to collect directly to the receiving facility, the billing is a maximum of 4 (four) visits within 1 (one) month.

c. If it is still not paid, Dept Account Revieble (AR) through collectors send a subpoena (warning) 1, which is the deadline given seven (7) working days, to the receiving facility to pay. If the subpoena 1 was not responded, then the 
Depi Account of Revieble (AR) through the collector sends again the second to the 2 (two) whose time limit is also 7 (seven) working days. If it is still not paid, the recipients are still given the opportunity to make payments through cashiers of PT.Federal International Finance (FIF) Branch of Bengkulu and collector before entering Over Due (OD) $<60$ days of delay, if the Over Due (OD)> 60 days of delay, in the system receiving facility falls within the bad credit or commonly called " problem loans" are in a bookkeeping term financing institution known as "non-performing loans" (NPL).

After all the above provisions are passed, if the customer still does not perform its obligations, the PT.Federal International Finance (FIF) Branch of Bengkulu make other approaches, but if the approach is not achieved then the PT.Federal International Finance (FIF) Bengkulu Branch conduct execution with due regard to the applicable regulations and maintaining the rights of customers.

The fiduciary warranty execution of delinquent customers must be in accordance with the principle of customer protection where customer protection is an important matter, every object of credit must be registered by the leasing to the Ministry of Justice and Human Rights as disclosed by Bunyamin as Head of Legal Services and Human Rights Division of Bengkulu that every security object must be registered through fiduciary registration. It shall be effective as of March 5, 2013 as stipulated in the Regulation of the Minister of Justice and Human Rights No. 10 of 2013 on the online registration system through notary and the notaries who are authorized to enter data Fiduciary Warranty requirements electronically. ${ }^{9}$

According Bunyamin as Head of Legal Services and Human Rights Division of Bengkulu, the Fiduciary Warranty registration

9 The interview results conducted by the author with Bunyamin as the Head of Legal Services and the Human Rights Division of Bengkulu 
mechanism or Fiduciary Warranty certificate shall be filed by the fiduciary, the authorized or deputy to the Ministry of Justice and Human Rights of the Republic of Indonesia through a notary with the application system provided. After the Fiduciary Warranty is registered by the Ministry of Justice and Human Rights perform its role by monitoring the fiduciary security data that has been registered with the $A H U$ Online application system. ${ }^{10}$

Based onBunyamin as Head of Legal Services and Human Rights Division of Bengkulu, the Ministry of Justice and Human Rights can only monitor the registration of Fiduciary Warranty by leasing through the application and cannot go directly to the field, it can actually cause problems for the Ministry of Justice and Human Rights of Bengkulu cannot be viewed directly and fiduciary real number that has been registered and not registered.This can actually impact on the confiscation system that will be done by the leasing,

10 The interview results conducted by the author with Bunyamin as the Head of Legal Services and the Human Rights Division of Bengkulu especially until now there has been no sanctions imposed on leases that do not register fiduciary Warranty. ${ }^{11}$

The sanctions that have never been given by the Ministry of Justice and Human Rights of Bengkulu made a lot of Bengkulu leasing who did the cheating and harming customers while execution. In addition, based on the interviews with several sources that the author of the research samples showed that between the statements expressed by the FIF is inconsistent with the facts on the ground, it can be seen from the following interview:

1. Sumartini having address at MuaraBangkahulu Subdistrict, as entrepreneurship job. According to Sumartini, the motor vehicle that has been credited through PT. Federal International Finance Branch of Bengkulu for 3 years and has been running for 1 year experienced a delay in payment for three months, the delay is due because

11 The interview results conducted by the author with Bunyamin as the Head of Legal Services and the Human Rights Division of Bengkulu 
sumartini business losses and economic difficulties,

Sumartini was requested due time, but before the due time expires, PT. Federal International Finance Bengkulu Branch has come bringing the motor vehicle. Without giving the enough time to Sumartini to make other efforts or to give the due time, the motor vehicle confiscation itself was done by FIF with force by asking Suhartini to sign the news letter which previously could not be read clearly by Sumartini. $^{12}$

2. Robert, the residents of GadingCempaka village who works as laborer admit the same thing as Sumartini said that when Robert delayed the payment for 4 months, Robert Admitting the similar thing to that disclosed by Suhartini where in carrying out the execution of the FIF efforts enforced without regard to the rights of Customers.

12 The author's interview results with Sumartini as the debtor in the financing agreement between the debtors with creditors of PT. Federal International Finance Branch Bengkulu. On Saturday, September $2^{\text {nd }}, 2017$
3. SryHartati who works as a teacher that delayed payment because her previous motor vehicle was lost but rediscovered after a few months later, this loss makes SryHartati do not pay the installments for a few months and it is considered as a breach of contract by the leasing, and the resulted after the motor vehicle is secured by the relevant authorities, the motor vehicle is drawn and controlled by the PT. Federal International Finance Branch of Bengkulu.At theconfiscation timeof the PT. Federal International Finance Branch of Bengkulu cannot provide the certificate of fiduciary registration against confiscation when the vehicle is not in the Sry's hands.

The result indicated the dishonest act done by FIF regarding to execution on collateral object led to legal issue. This finding was in line with the opinion given by Ministry of Law and Human right of Bengkulu (KEMENKUMHAM) that many executions on collateral object were not based on the proper regulation. It is known that the execution can only 
be done if the collateral object has been registered under fiduciary Warranty. If the certificate of fiduciary Warranty is not available then leasing cannot directly withdraw the collateral object resulting the execution should be under the trial court's order where the certificate states "For the sake of justice of the Devine God". It also means that the execution holds the same legal power as the court sentence. $^{13}$

Based on the facts, FIF had taken action that contradicted the principle of justice and balance which also violated the constitution. It was regarding to FIF that executed the collateral objects where those objects had not been registered under fiduciary Warranty. The action taken by FIF indicated the breach of liability done by debtor and this was contradictive with the liability theory of Abdulkadir Muhammad such as the following: ${ }^{14}$

1) Intentional Tort Liability

According to writer's analysis, liability on intentional tort was not reflected in relation between debtor and creditor where debtor deliberately postponed the installment and did not have any

\footnotetext{
${ }^{13}$ Interview result with Bunyamin, Chief of Legal Service and Human Right Division of Bengkulu.

${ }^{14}$ Abdulkadir Muhammad, Hukum Perusahaan Indonesia, Citra Aditya Bakti, 2010, pg.503.
}

intention to fulfill his liability any sooner as it was stated in the agreement that bound both parties. The lack of liability led the creditor to execute the collateral objects. This action was done based on the agreement that had been determined and agreed by both parties.

2) Negligence Tort Liability based on the Concept of Fault that is related to intermingle of Moral and Legal.

Based on the analysis, liability on negligence tort is not found. Since the liability on negligence tort is not found, the creditor executed the collateral objects.

Based on the analysis, two theories of liability that should be followed by the debtors were not done successfully, and it created problem between the creditor and debtor resulting creditor executed the collateral object as it was stated in the agreement between both parties. However, the execution done by FIF in reality did not follow the applied regulation, execution was done without fiduciary certificate as it is regulated in constitution. This also did not reflect the legal protection as it was stated by Salim and Erlies where protection or the purpose of the protection was not found. The protection in fiduciary Warranty 
execution has not been reflected and implemented where creditor prioritize its right but put aside debtor's right.

Moreover, execution done by FIF on collateral object that had not been registered its fiduciary reflected the lack of preventive and repressive protection as the following:

a) Preventive Protection

Preventive legal protection is the protection provided by the government in order to prevent the possibility of violation. However, based on writer analysis, this protection was not implemented. This was based on the lack of sanction and clear regulations regarding to leasing company that does not register fiduciary collateral. Besides, the lack regulation regarding to fiduciary collateral execution led the leasing applied its company procedures in execution, and it opened the possibility of violation on debtor's rights and did not provide protection to the customers.

b) Repressive Protection

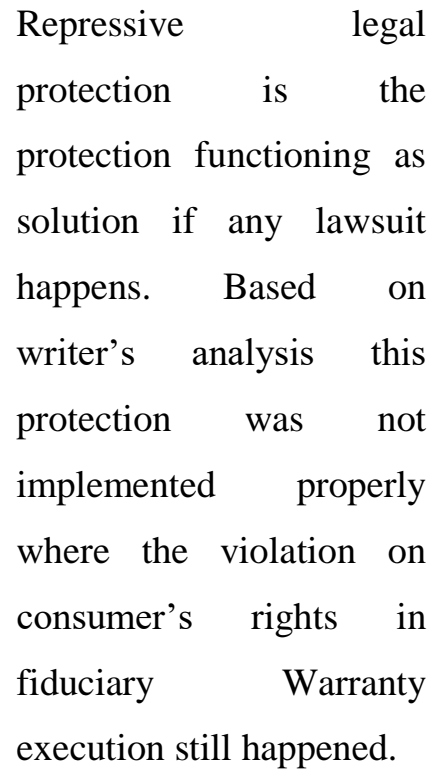

Based on the explanation above, it can be concluded that the execution done by leasing company, FIF, started when debtor had not fulfilled the liability properly as it was stated in the agreement. This led FIF as creditor took an action of execution on collateral object though the execution sometimes did not follow the procedures and legal regulations. Execution on collateral objects that had not been registered in fiduciary Warranty or do not have fiduciary certificate contradicted the constitution and violated the principle of costumers protection where they have rights to get clear information related to their collateral objects.

Consumer protection on collateral execution without fiduciary registered in PT. Federal International Finance (FIF) Branch Bengkulu could only be implemented if both parties 
fulfilled their rights and responsibility proportionally. Besides, the protection on consumers could be established if government fulfilled its role to provide preventive protection through clear regulations on collateral execution that regulated sanction for any breach of agreement.

\section{CLOSING}

\section{Conclusion}

The implementation of Consumer protection on collateral execution without fiduciary registered in PT. Federal International Finance (FIF) Branch Bengkulu had not been in line with the regulations. The execution done by PT. Federal International Finance (FIF) Branch Bengkulu was neither supported with fiduciary certificate nor mediation effort in prior to execution process. Thus, the execution on collateral object without fiduciary registered violated the debtor's rights as consumer.

\section{Suggestions}

Based on the conclusion, researcher offered suggestions as the following:

1. Government has to release the specific regulations regarding to execution on fiduciary collateral objects.

2. Government should optimize the control function on

$$
\begin{aligned}
& \text { surveillance of fiduciary } \\
& \text { Warranty registration and } \\
& \text { sanction policy for creditors } \\
& \text { that violate the regulations. }
\end{aligned}
$$

\section{BIBLIOGRAPHY}

Abdulkadir Muhamad, Hukum dan Penelitian Hukum, Citra Aditya Bakti, Bandung, 2004.

Bahder Johan Nasution, Metode Penelitian Ilmu Hukum, Mandar Maju, Bandung, 2008.

Dahlan Siamat. Manajemen Lembaga Keuangan,Edisi Kedua Fakultas Ekonomi Universitas Indonesia, Jakarta, 2001

Kasmir. Bank dan Lembaga Keuangan Lainnya. Jakarta : Rajawali Pers. 2008

Salim HS. Perkembangan Hukum Jaminan Di Indonesia, PT Raja Grafindo Persada, Jakarta, 2014

Sirman Dahwal, Pelaksanaan Perkawinan Beda Agama (Studi Berbagai Kasus Di Indonesia Priode Tahun 19862010), Jurnal Ilmu Hukum Bengkoelen Justice,Program Pasca Sarjana Ilmu Hukum vol.2.No.2.2012 